\title{
El avance del dequeísmo en el siglo XIX: factores desencadenantes*
}

\section{The advance of dequeism in the $19^{\text {th }}$ century: triggering factors}

\author{
Ana Serradilla Castaño \\ Universidad Autónoma de Madrid \\ ana.serradilla@uam.es \\ ORCID iD: http://orcid.org/0000-0002-8862-2458
}

RESUMEN: En este estudio se analizan los casos de dequeísmo aparecidos en el siglo XIX. Se parte de los datos obtenidos en diversos corpus y se observan los tipos de verbos con los que se documenta el dequeísmo, el tipo de construcciones en las que aparece, la cronología de los ejemplos, así como factores lingüísticos (semántico-pragmáti$\cos$, sociales y psicolingüísticos) o extralingüísticos (procedencia de los textos, tipos de escrito, nivel cultural de los hablantes...) que pueden resultar decisivos para su aparición en el discurso.

Palabras clave: dequeísmo, siglo XIX, variación, factores lingüísticos, factores extralingüísticos.

ABSTRACT: This paper deals with the cases of dequeism documented in the $19^{\text {th }}$ century. It is based on data obtained from different corpora and aims at seeing what type of verbs were involved in dequeism, as well as the type of constructions in which they appeared and the chronology of the examples. Likewise, it also tries to determine the factors that may have been influential for their emergence in the speech, taking into consideration linguistic factors (of a semanticpragmatic, social or psycholinguistic nature) or extralinguistic factors (text sources, types of writings, cultural level of the speakers ...).

Keywords: dequeism, $19^{\text {th }}$ century, variation, linguistic factors, extra-linguistic factors.

* Este trabajo ha sido llevado a cabo en el marco del Proyecto de Investigación "Cambio gramatical en el español europeo: problemas teóricos y avances empíricos”, FFI2015-64722-P, dirigido por Inés Fernández-Ordóñez y Javier Elvira.

Copyright: ( 2017 CSIC. Este es un artículo de acceso abierto distribuido bajo los términos de una licencia de uso y distribución Creative Commons Attribution (CC-by) España 3.0. 


\section{INTRODUCCIÓN}

El dequeísmo, fenómeno cada vez más extendido en español, ha llamado la atención de muchos investigadores en los últimos años. Hay que destacar, no obstante, que la gran mayoría de los trabajos publicados centra su interés en la extensión de esta construcción en español contemporáneo y son casi una excepción aquellos que tratan la presencia de dequeísmos desde una perspectiva diacrónica: entre estos últimos podemos señalar los estudios de Canet Villar (2012), Cano Aguilar (1977-1978 y 1985), del Barrio (2005), del Moral (2008), Delicado Cantero (2013a, 2013b, 2014), Orellano de Marra (2008), Sánchez Lancis (2006, 2012 y 2014) o Serradilla (2014 y 2015), que se ocupan de la evolución del régimen preposicional en diversos momentos de nuestra historia lingüística.

Coincido plenamente con uno de estos investigadores, Carlos Sánchez Lancis (2014), cuando afirma que explicar un fenómeno como este con datos únicamente del español actual resulta insuficiente, ya que se pierden de vista sus orígenes, las causas iniciales de este cambio sintáctico e, incluso, la situación sociolingüística en la que comienza a aparecer. Teniendo en cuenta este punto de partida, en trabajos anteriores me he ocupado de la situación del español medieval y clásico, y recientemente he realizado el seguimiento de las construcciones dequeístas en el siglo XVIII (Serradilla, 2014 y 2015). En este estudio me centraré en el análisis de los casos de dequeísmo documentados en el español del siglo XIX y daré cuenta de algunos de los factores más relevantes que influyen en su aparición y en su extensión. Con ello contaremos con un panorama de la evolución del dequeísmo en las épocas previas al siglo XX, momento en el que esta construcción vive un importante auge.

En primer lugar, se hace necesario destacar que en el siglo XIX el régimen verbal se encuentra ya fijado y encontramos las mismas construcciones cuando el complemento es una oración, un nombre o un infinitivo (habló de ella, habló de compensarle o habló de que lo harían). Persisten aún los casos de queísmo, herederos de las construcciones medievales y clásicas: confío que, habla que... (Serradilla, 1995, 1996 y 1997), pero lo más habitual es encontrar las construcciones que hoy en día consideramos canónicas. En este sentido, es posible afirmar que usos como hablar de que, acusar de que, persuadir de que... son estructuras absolutamente asentadas en el sistema lingüístico del español.

En Serradilla (2014) mencionaba la situación del dequeísmo en el siglo XVIII (107 ejemplos) y en este trabajo, en el que se avanza cronológicamente, pretendo analizar cuál es la evolución de este fenómeno en el siglo XIX: la casuística, las construcciones en las que predomina, las causas de su aparición, el tipo de texto en el que aparece y la procedencia de los ejemplos.

Antes de entrar de lleno en el análisis de los datos y de las causas del dequeísmo, me detendré en unas brevísimas reflexiones en torno a la presencia 
de la secuencia de que en este siglo. Quiero aclarar que en este primer momento no estoy hablando solo de casos de dequeísmo o de construcciones completivas. En total, desde 1800 hasta 1899 en CORDE se documentan 45047 casos de de que en 1910 documentos. Dichos documentos presentan una tipología muy variada: prosa jurídica, prosa narrativa, prosa histórica, etc. (solo se han localizado 788 casos en verso). Respecto a la procedencia, aunque el mayor número de textos proviene de España y, por tanto, así ocurrirá también con el número de ejemplos, también hay documentos del resto de países hispanohablantes.

Si comparamos esta situación con la de siglos precedentes, observamos que en la centuria anterior el número de casos de la secuencia de que es de 19246 casos en 1778 documentos, con lo que resulta evidente que esta estructura tiene un crecimiento exponencial en el XIX. En el siglo XVII hablamos de 29608 casos en 1574 documentos, casi 10000 más que en el siglo siguiente y, por último, en el XVI, siglo en el que empezamos a encontrar el fenómeno del dequeísmo, encontramos algunos casos menos de la secuencia de que, pero siempre por encima de los del XVIII y menos de la mitad de los casos que en el XIX: 21490 casos en 1850 documentos. Es, pues, el XIX el siglo con más presencia de de que, a excepción, obviamente del $\mathrm{xx}$, donde solo en CORDE (hasta 1975) se localizan 51254 casos en 2479 documentos.

Estos datos nos orientan en una dirección clara, también considerada por Sánchez Lancis (2014: 191): el desarrollo progresivo en español de la secuencia de que, con un paréntesis en el siglo XVIII, atribuible en gran parte a la menor documentación con la que contamos. También nos permiten entender que, a medida que la secuencia sea más frecuente y que, por lo tanto, a los hablantes les resulte más familiar, podremos encontrar mayor número de casos de dequeísmo, es decir, de casos de de que no canónicos. Para que una estructura como esta prospere, se precisa, obviamente, que su uso esté extendido en el sistema lingüístico en otras construcciones, lo que queda demostrado con los datos anteriormente expuestos ${ }^{1}$.

A continuación, una vez asumida la frecuente presencia de la secuencia de que en el español del siglo XIX, se presentarán los casos de construcciones dequeístas localizados y ya avanzo que son casi el doble que en el siglo anterior, aunque su presencia frente a las formas canónicas sigue siendo mínima.

\footnotetext{
${ }^{1}$ En la época medieval la presencia en $C O R D E$ de la secuencia de que es aún minoritaria, aunque sufre un importante avance a lo largo de los siglos: 51 ejemplos en el siglo XII (en 9 documentos), 2520 en el XIII (en 374 documentos), 2031 en el XIV (394 documentos) y 5912 en el siglo XV (en 822 documentos). Lo habitual es que esta secuencia funcione durante esta época como introductora de oraciones temporales - uso que, poco a poco, va desapareciendo es español- o encabezando oraciones relativas.
} 


\section{CORPUS UTILIZADO}

El corpus manejado en esta investigación está formado por todos los casos de de que documentados en el XIX en el CORDE, en el CORDIAM y en el corpus sociolingüístico de Blas Arroyo ${ }^{2}$. En el caso del CORDE se ha hecho una búsqueda año a año para atender a todos los posibles casos de dequeísmo. Dado que este corpus no permite recuperar más que 1000 ejemplos por búsqueda, hay algunos años — en los que la presencia de de que era superior a 1000 — en los que ha sido necesario realizar algunos filtros ${ }^{3}$. En el caso del CORDIAM se han analizado todas las apariciones de la secuencia de que en los textos americanos del siglo XIX (302 documentos en total, de los que en 131 de ellos aparecen ejemplos de dicha secuencia). Por otro lado, el corpus manejado se complementa con los textos del siglo XIX recogidos por Blas Arroyo en su Corpus sociolingüístico diacrónico (correspondencias, diarios, memorias y escrituras populares), donde se incluyen informes, cartas, relatos o diarios de emigrantes a América. Dicho corpus consta de 18 archivos que suponen un total de casi 2000 páginas.

En todo este corpus se han documentado 204 ejemplos de dequeísmo. Para este cómputo he eliminado algunos ejemplos dudosos. Así, igual que hice al analizar los casos de dequeísmo en el siglo XVIII (2014: 932), he decidido no considerar como dequeísmo los casos de necesitar de que, ya que, aunque lo más habitual es la construcción directa, la construcción necesitar de es también frecuente ante nombre e infinitivo. Por esta razón, ejemplos como los siguientes, frecuentísimos en la época, quedan fuera de este trabajo ${ }^{4}$ :

1. Sofrónia. Esta regla, que será sin duda muy buena, es sobrado general para mí, que no tengo experiencia todavía. Necesito de que me instruyas mas por menudo. (1801, Masdeu, Juan Francisco de: Arte poética fácil, España) ${ }^{5}$.

\footnotetext{
2 "Corpus sociolingüístico diacrónico (correspondencias, diarios, memorias y escrituras populares)", proyecto realizado con la financiación del Ministerio de Ciencia y Tecnología (FFI2010-15280), 2012.

3 Así, en 1849 ha sido necesario realizar un filtro porque había 1075 ejemplos de de que. Finalmente, se han analizado 957. De 1868 (1041 casos) se han analizado 616 ejemplos. En 1876 he tenido que hacer un nuevo filtro porque hay 1990 casos y he accedido a 761 ejemplos. En 1880 ya hay más de 2000 casos y vuelve a hacerse necesario el filtro: todos los ejemplos, salvo 81 documentos provenientes de América (que no son de dequeísmo), son españoles; analizo los americanos y 209 ejemplos de textos españoles. En 1881 hay casi 3000: accedo a todos los americanos (186) y a 239 españoles. En 1884 analizo los 707 ejemplos americanos y, de España, 166. En 1885 he podido trabajar con 345 ejemplos de Cuba y Chile, y con 569 de España. Por último, en 1889 también filtro: 182 de América y 282 casos de textos peninsulares. El resto de los años ha sido analizado teniendo en cuenta la totalidad de los datos.

${ }^{4}$ En esta misma línea se posiciona Delicado (2014) frente a algunos autores que incluirían tales ejemplos como dequeísmos.

${ }^{5} \mathrm{Al}$ citar los ejemplos, se especificará CORDIAM si el documento pertenece a dicho corpus o BA, si está extraído del corpus seleccionado por Blas Arroyo. En el caso de que no se añada ninguna marca, se trata de ejemplos del CORDE.
} 
2. - Vos necesitáis de que mi voz aplaque a la multitud irritada; no porque temáis el riesgo que podáis correr personalmente, pues me consta que tenéis valor; sino porque no os conviene ser la causa de una grave perturbación del orden. (1867, Milla y Vidaurre, José: El visitador, Guatemala).

3. Por lo cual, Tomás Moro en su Utopia resolvió que no era posible conservarse ninguna monarquía muchos años, en que las haciendas no fuesen comunes, porque son el cuerpo natural, que necesitan de que sea común en proporción á todos, para su conservación (1898, Costa, Joaquín: Colectivismo agrario en España, España).

Me limitaré, pues, a ejemplos claros de dequeísmo y comentaré los casos que pudieran plantear alguna duda en su lectura.

\section{ANÁLISIS DE LOS DATOS}

\subsection{Cronología de los datos}

Como ya he avanzado, he analizado todos los casos de dequeísmo aparecidos en el CORDE en el siglo XIX (1800 a 1899). Mi intención es observar si hay algún avance significativo a medida que va transcurriendo el siglo. En todo caso, quiero llamar la atención sobre el hecho de que en 52 de los 100 años analizados no se documenta ningún ejemplo de dequeísmo ${ }^{6}$. A continuación, aparecen desglosados, por décadas, los datos numéricos:

\begin{tabular}{|c|c|}
\hline Décadas & Número de apariciones \\
\hline $1800-1809$ & 15 \\
\hline $1810-1819$ & 17 \\
\hline $1820-1829$ & 25 \\
\hline $1830-1839$ & 7 \\
\hline $1840-1849$ & 12 \\
\hline $1850-1859$ & $35(20)^{7}$ \\
\hline $1860-1869$ & 6 \\
\hline $1870-1879$ & $56(7)$ \\
\hline $1880-1889$ & 8 \\
\hline $1890-1899$ & 21 \\
\hline
\end{tabular}

\footnotetext{
${ }^{6}$ No hay ejemplos de dequeísmo en 1802, 1804, 1807, 1810, 1814, 1815, 1817, 1821, 1824 $1827,1829,1830,1831,1835,1837,1838,1839,1840,1841,1846,1848,1851,1852,1854$, 1856, 1857, 1858, 1859, 1860, 1862, 1864, 1865, 1866, 1867, 1869, 1870, 1873, 1875, 1876, $1877,1880,1881,1885,1886,1888,1891,1892,1893,1894,1896,1897$ у 1898.

${ }^{7}$ El significado de los números entre paréntesis será explicado a continuación.
} 
Esta evolución puede verse de manera más clara en el siguiente gráfico:

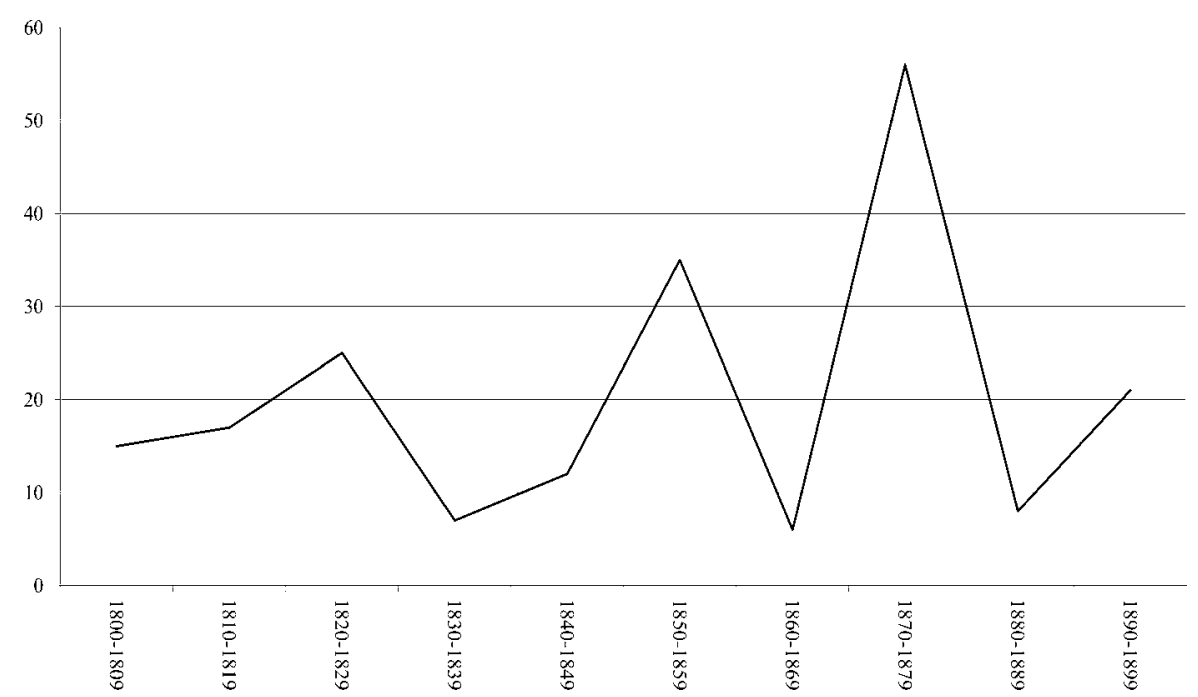

FIGURA 1.-Número absoluto de casos de dequeísmo en el siglo XIX

Como puede observarse, las décadas con más presencia de dequeísmo son la de los cincuenta y la de los setenta, seguidas de los años veinte y los años noventa. De todas formas, esta información hay que matizarla, ya que la mayor parte de los ejemplos provienen de unas pocas obras. Una de ellas, fechada entre 1850 y 1900 (y que he incluido en la década de los cincuenta, aunque podría haber sido incluida en cualquier otra década de la segunda mitad del siglo) recoge distintos fragmentos de lírica romanceril (habla más popular) y presenta 12 casos de dequeísmo; otra de 1853, Paulino Lucero, de Hilario Ascasubi, imita el habla de los gauchos y entre los rasgos supuestamente vulgares de esta habla se incluye el dequeísmo (15 casos). El mismo autor, en 1872, en otras dos obras en las que se intenta reflejar el habla gauchesca también presenta muchos casos de dequeísmo: 49 ejemplos.

Teniendo en cuenta estos datos, si eliminamos de nuestro cómputo los casos de habla artificial, observamos que en la década de los cincuenta, la cifra se reduciría a 20, entre los que se incluirían los ejemplos de habla más popular reflejada en los romances. En el caso de los setenta, la cifra de dequeísmos quedaría reducida a 7 casos. La línea evolutiva, teniendo en cuenta estas restricciones, sería la que aparece en el siguiente gráfico: 


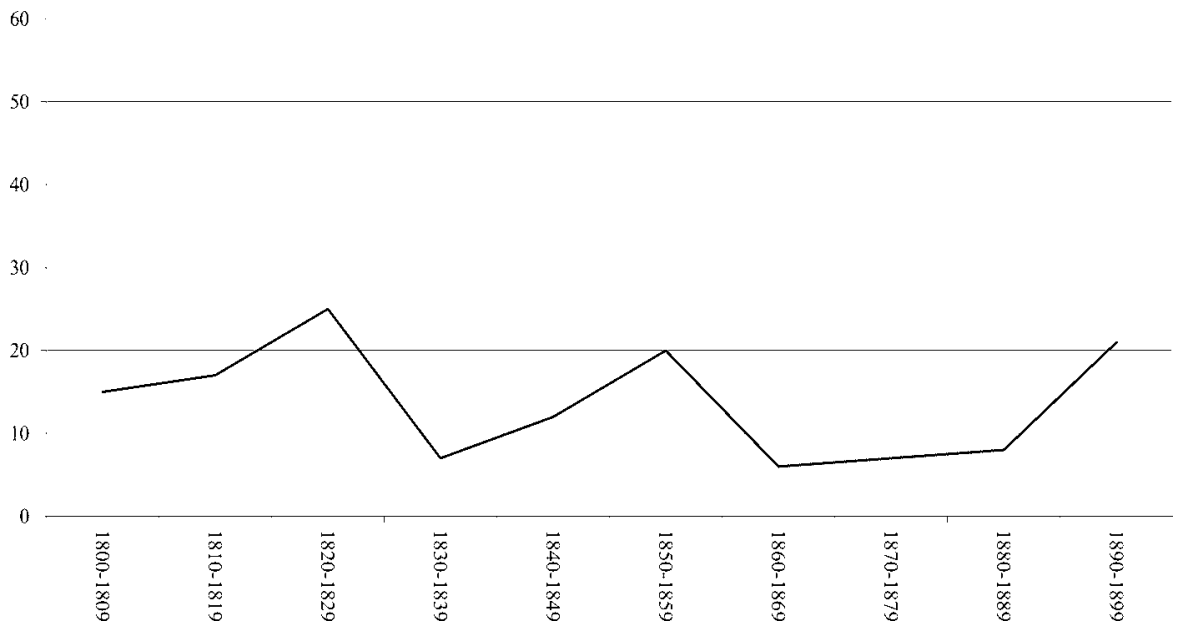

FIGURA 2.-Cronología del dequeísmo en el siglo XIX

Por otro lado, en los noventa, de los 21 ejemplos documentados, 17 son de una misma obra chilena. También en los años veinte, momento con más ejemplos después del filtro realizado, observamos que 16 de los ejemplos se incluyen en una obra de 1822 que recoge muestras de lírica romanceril.

A la vista de los datos, no parece notarse un importante incremento de esta construcción ni un momento de máxima frecuencia en este siglo, pues es el tipo de texto el que resulta determinante, mucho más que la evolución cronológica. En este sentido, aunque se ha visto un importante incremento del dequeísmo respecto a siglos anteriores, realmente es imposible, con los datos con los que cuento, dibujar una línea ascendente que refleje el avance de esta construcción a lo largo del siglo y que anticipe la eclosión del dequeísmo en el siglo siguiente.

\subsection{Tipo de verbos con los que se documentan casos de dequeísmo}

Para profundizar en la realidad del dequeísmo se hace necesario estudiar los tipos de verbos con los que es posible encontrar esta construcción. Con este fin he elaborado una clasificación de dichos verbos para la que he tenido en cuenta la realizada por Serradilla (1997) ${ }^{8}$ con algunas incorporaciones de Del Moral (2008):

${ }^{8}$ En esta última obra la clasificación es mucho más detallada, pero, dado el mínimo número de ejemplos con que contamos en este siglo, no resulta rentable realizar más subdivisiones. 
Verbos de comunicación: afirmar, alegar, acreditar, amonestar, argüir, asegurar, certificar, confesar, contar, contestar, decir, denunciar, manifestar, negar, participar, proponer, redargüir, responder, testificar (sacar más respuesta sino de que ${ }^{9}$.

Verbos de proceso cognitivo: advertir, (a)figurarse, conocer, creer, entender, imaginar, juzgar, opinar, recordar, reparar, saber, suponer, tragarse, tener presente, darse por entendido, hallar imposible.

Verbos de emoción: aplaudir, asombrar, celebrar, confiar, desear, esperar, pesar, querer, sentir, soñar, temer.

Verbos de mandato y petición: imponer, mandar, pedir, permitir.

Verbos de acuerdo: acordar, convenir, dar por bueno, estar de acuerdo.

Verbos de percepción física: mirar, sonar, ver.

Verbos copulativos: ser, parecer.

Expresiones con el verbo ser: ser fácil, ser justo, ser mejor, ser menester, ser seguro, ser verdad.

Otros verbos: agradecer, aprovechar, buscar, conceder, conseguir, constar, disponer, echar en cara, enseñar, evitar, ocultar, ponerse, resultar.

Locuciones conjuntivas: puesto de que.

Otras construcciones: salir a alguien de que, por lo mismo de que.

Como puede observarse, los verbos con los que más frecuentemente aparecen las construcciones de dequeísmo son los de comunicación y los de proceso cognitivo. Estos datos coinciden con los de Del Moral (2008: 196), aunque en

\footnotetext{
${ }^{9}$ Con esta expresión se ha localizado un ejemplo en el que conviven la construcción dequeísta y la solución canónica: "Así, por más súplicas y consideraciones que su hermana le hizo para que aquellos debates cesasen, y quisiese perdonar a su esposo y sus primos, quedando las cosas en el estado que venían antes de la desventurada tentativa, no pudo sacar más respuesta sino de que por su honor le convenía a él entrar en los reinos de ellos, como ellos lo habían hecho en el suyo; $y$ que si en adelante el rey de Aragón se enmendaba y le guardaba los respetos que lo debía, él se los guardaría a él y miraría por su honor, según el deudo que había entre los dos." (1832, Quintana, Manuel José: Vidas de Vasco Núñez de Balboa, Francisco Pizarro... España).
} 
su caso, aparte de estos verbos, hay una mayor frecuencia en el grupo de los verbos copulativos ${ }^{10}$.

Yendo a verbos concretos, observamos que las documentaciones más frecuentes se dan con los verbos saber (22), decir (21), denunciar (10) $)^{11}$, asegurar (9), confiar (8), pesar (6), ver (6), confesar (4), contar (4), esperar (4), responder (4), argüir (3), creer (3), entender (3) imponer (3), querer (3) y resultar (3); la estructura sujeto + ser + de que aparece en 12 ocasiones. De los demás hay un solo ejemplo o, a lo sumo, dos a lo largo de todo el siglo.

Estadísticamente, si consideramos el número de apariciones, nos encontramos con los siguientes porcentajes:

Verbos de comunicación:

Verbos de proceso cognitivo:

Verbos de emoción:

Verbos copulativos:

Verbos de percepción física:

Verbos de mandato y petición:

Verbos de acuerdo:

Locuciones conjuntivas:

Otros verbos:

Otras construcciones:

$$
\begin{array}{r}
33,82 \% \\
21,57 \% \\
14,7 \% \\
9,8 \% \\
3,92 \% \\
3,43 \% \\
2,45 \% \\
0,49 \% \\
8,33 \% \\
1,47 \%
\end{array}
$$

Observamos, pues, cómo los verbos de comunicación, los de proceso cognitivo y, en tercer lugar, los de emoción son aquellos que con más frecuencia aparecen en construcciones dequeístas. Veamos una muestra:

Verbos de comunicación $(33,82 \%)$ :

4. reciví la mui apreciable tuya con fecha del 19 de abril en la que me manifiestas de que no te dan la licencia para ir adonde está nuestros hermanos, pues te doi la licencia y poder y juntamente de mi padre y tus hijos para que pases libremente. (Carta conyugal, no aparecen los nombres Miera, 8.V.1812, Historias de América. La inmigración en tinta y papel, BA).

5. Dicen de que el Diretor / de la docena del fraile, / el veinticinco dió un baile (1872, Ascasubi, Hilario: Aniceto el Gallo, Argentina).

Verbos de proceso cognitivo $(21,57 \%)$ :

6. creyó, sin duda, que se encontraba en camino de adquirirse por sí propio lo que para su perfeccionamiento faltaba, y aun opinamos de que sus deseos

\footnotetext{
${ }^{10}$ Este autor usa el Corpus del Español de Davies y documenta en el siglo XIX un total de 138 casos de dequeísmo.

${ }^{11}$ En este caso hay que aclarar, sin embargo, que todos son de la misma obra.
} 
fuesen los de no merecer nada á ningun otro matador de los que actuaban por la época de su aparicion. (1836-1876, Anónimo: Arte de torear á pié y á caballo, España).

7. Has de saber, dulce Albano, / de que la cruel violencia / de nuestro padre iqué ahogo! / ejecutó, igrande pena! / la mayor crueldad en mí, / que otra imposible se vea. (c 1850-1900, Navarro, Pedro: San Albano. Nueva y curiosa relación, en que se da cuenta... España).

Verbos de emoción $(14,7 \%)$ :

8. ¿No te estremeces tú, alma de Caín? —añadió, mirando a Jimeno-. ¿No te asombra de que haya quien sea capaz de envenenar a una mujer tan hermosa y tan inocente? (1834, Espronceda, José de: Sancho Saldaña o El Castellano de Cuellar, España).

9. Y sin otro particular por hoy te deseo buena y completa salud, por la que no se me pasa día sin rogar, así como de que tengas una feliz suerte si te conviene. Adiós, adiós, tu hermano (Pedro Jado a su hermano Ventura, Escalante, 1855 junio, 12. Para hablarte, XIX, 2, BA).

Verbos copulativos $(9,8 \%)$ :

10. Yo les preguntaba qué iban a hacer, que era menester meditar cualquiera cosa, y de que se fueran con tiento en gastar, porque no sabíamos si la Providencia dispondría que fuera el último socorro. (c 1818, Fernández de Lizardi, José Joaquín: La Quijotita y su prima, México).

11. El señor Fraile (obispo de Siguenza) sin embargo del gran murmullo que constantemente reinó en las galerias durante su discurso, á pesar de las invitaciones que hizo al orden presidente tocando repetidisimas veces la campanilla, pudimos entender que su opinion era de que debia declararse haber lugar á votar sobre la totalidad de estos proyectos (1822. Anónimo: "Presidencia del señor Giraldo" [El Imparcial, 5 de febrero de 1822], España).

Verbos de percepción física $(3,92 \%)$ :

12. Y aquesta feliz empresa / Dió motivo á que entibiasen / De los sitiados las fuerzas, / Viendo de que ya el castillo / Era fuerza se rindiera. (p 1822, Anónimo: Romances, en Toma de Sevilla por el santo rey don Fernando, España). 13. Se suena de que, como el Diretor anda hoy por Palermo, olfatiando para los barcos de guerra uropeos, la Comendancia General de Marina está atariada haciéndole poner, con los mesmos barcos que fueron de Vuecelencia, tapones por todos laos, desde Patagónica hasta San Nicolás y más allasito, y que los barcos van cargaos de choclos para los empleaos de las duanas del Diretor, y llevándoles memorias del bocleo. (1872, Ascasubi, Hilario: Aniceto el Gallo, Argentina) $)^{12}$.

${ }^{12}$ Obsérvese cómo en este ejemplo conviven la construcción dequeísta y la solución canónica. 
Verbos de mandato y petición $(3,43 \%)$ :

14. Me persuadia que la que a este se me diera, si me fuese tan perjudicial como efectivamente lo es, mediante a que se dirige, Segun se me ha informado en la escribania de Camara que Vuestra Alteza manda de que aquel Teniente informe sobre los echos, ha que me contraigo. / Hesta providencia la obedesco como pronunciada, y manda se cumpla por Vuestra Alteza y me conformo con eso, librandose la Real probicion, pero nó sin las circunstancias presisas, y mas equibalente ha la inclinacion de Vuestra Alteza (1809, "Queja de Manuel Senon Gutierres ante los violentos procedimientos cometidos en su contra por el teniente del pueblo de Chaguaramal", Venezuela, CORDIAM $)^{13}$.

15. Vaya pronto por favor, / se lo mando, y digalés / a mis soldaos, de que yo/ les pido de que se vuelvan; (1872, Ascasubi, Hilario: Santos Vega, el payador, Argentina).

Verbos de acuerdo $(2,45 \%)$ :

16. Dando por bueno de que el Gobierno estuviera muy lejos de creer que los norteamericanos daban á la palabra controle la interpretación de dominio, porque en inglés significa inspeccionar, siempre resulta que dada la desesperada situación de Manila, que de un momento á otro podría rendirse á las fuerzas de Dewey y Marrit, debía haberse hecho constar en el Protocolo que la soberanía de España en Filipinas quedaría indiscutible sobre lo que pudiera suceder por la guerra empeñada, (1899, Fité, Vital: Las desdichas de la patria, España).

17. El agua de la Salud / por ser la demás regalo, / valdrá cada carga un ojo, / que se nos van opilando / todas las mujeres, y esto / conviene de que lo hagamos, / porque de no hacerlo así / el mundo se irá acabando. (c 1850-1900, Anónimo: El bando de un alcalde nuevo. Publicado en un pueblo cerca de Madrid, España).

Locuciones conjuntivas $(0,49 \%)$ :

18. Mediante esto, es ilusoria la reflexión de que no tiene facultades de quitar un poder el que no le ha dado, puesto de que estando V. autorizado por mí para hacerlo, qualquiera cosa que V. determine la hago yo, y no la hace $\mathrm{V}$., en virtud de las facultades que le he dado para ello. (1828, Fernández de Moratín, Leandro: Cartas de 1828 [Epistolario], España).

Otros verbos $(8,33 \%)$ :

19. Yo agradezco de que Ud. tenga la bondad de manifestar que la desea, pero, persuadido de que no puede existir entre Ud. y yo ningún género de simpatía, renuncio a un honor que pudiera serme muy difícil de conservar. (1842-1843, Gómez de Avellaneda, Gertrudis: Dos mujeres, Cuba).

${ }^{13}$ Véase cómo en este documento también se dan dos casos de queísmo. 
20. Tratóse en ella (dice) de poner diques a la inundación clandestina de géneros por la vía de Panamá, Chile y Buenos Aires para evitar la extracción de la poca plata y oro que nos restan, y de que se acaben de arruinar la agricultura, las artes y el comercio del país que tanto han padecido por esta causa. (1816, Quirós, José María: Memoria de instituto en que se demuestra que los muchos puertos nuevamente habilitados en América... México).

Otras construcciones $(1,47 \%)$ :

21. - Vaya, que el diañu seis las mozas de ahora. Ca día vos ponéis un amenículo nuevo. De modo y manera que una se despistoja para cortar bien un vestido, y al cabo le salen a usté con que le falta esto o le falta lo otro, y de que no está al estilo, y que torna y que vira. (1871, Pereda, José María de: Tipos y paisajes, España).

\subsection{Construcciones en las que aparece el dequeísmo}

Por otro lado, se han tenido en cuenta, para presentar la extensión del dequeísmo en el siglo XIX, las construcciones en las que es posible documentar esta estructura; así, en cuanto a la posición de la construcción dequeísta con respecto al verbo, hemos de decir que la única estructura documentada es la posposición: no se encuentra ningún caso de anteposición.

En lo que concierne a la función desempeñada por el sintagma encabezado por de que, de forma abrumadora predomina la función de complemento directo, aunque hay también algunos casos (36) en que nos encontramos ante un sujeto posverbal. En estos últimos ejemplos nos encontramos con construcciones pasivas reflejas, con oraciones con ser o con otros verbos como pesar, contar o resultar. Asimismo, he localizado hasta 13 casos en los que lo que se observa es una confusión de la preposición.

Complemento directo:

22. Viviendo á su libertad, No juzgando de que hubiera Valor que los conquistase (p 1822, Anónimo: Romances, en Toma de Sevilla por el santo rey don Fernando, España).

23. Veremos lo que sale; pero no entiendo cómo se viene el Carlos, siendo guarda de esa Aduana. Tú me propusiste (aunque tarde) de que lo trajera conmigo. (1845, Olmedo, José Joaquín: A Francisco de Paula Icaza y Silva [Epistolario], Ecuador).

24. Salió fuera el renegado / enfurecido y soberbio, / a sus criados los manda / de que prendan á don Pedro / en una obscura mazmorra / y le cargasen de hierro, / y que no de dieran agua, (c 1850-1900, Fuentes, Pedro de: Doña Josefa Ramírez. Nueva relación en que se da cuenta de..., España). 
25. - Eso nada prueba — añadió otra-. Recordad cuando os seguía a todas partes vuestro malogrado primo el de las largas narices, y de que jurabais, sin embargo, y perjurabais que todo era con la mayor sencillez y desinterés más grande del mundo. (1861, Castro, Rosalía de: Flavio, España).

26. a no ser que los gobernantes sean lerdos o menesterosos, cosa que no hay por qué serlo, desde que todos obedecemos y sabemos de que son hombres necesarios para arreglar y asigurar la Provincia, (1872, Ascasubi, Hilario: Aniceto el Gallo, Argentina).

Sujeto:

Verbos pesar, constar, resultar...

27. Me consta de que no le desagradó mi oferta y mi buen celo. Éste no sosegaba con esta pasiva aprobación, que fue lo que pude arrancar a su constante indolencia. (1808, Capmany, Antonio de: Centinela contra franceses, primera parte, España).

28. - Pus bueno — continúa Tanasio—; ahora resulta de que como los ensalzaos no quieren entrar, nusotros los españoles paez que estamos abocaos a juzgarlos pa que entren, porque resulta que el francés es poderoso, y el caso es echarle allá los ensalzaos pa que dé cuenta de toos. (1871, Pereda, José María de: Tipos y paisajes, España).

29. Me pesa en el alma de que mi padre sea así; de que hable con irreverencia y burla de las cosas más serias; pero no incumbe a un hijo respetuoso el ir más allá de lo que voy en reprimir sus desahogos un tanto volterianos. (1874, Valera, Juan: Pepita Jiménez, España).

\section{Construcción pasiva refleja}

30. Tambien las hay de Azogue; pero no se trabajan estas por falta de fomento, ni se puede asegurar de que tenga cuenta su laboreo hasta profundar mas su terreno y reconocerle personas practicas en esta materia. (c 1793-p 1801, Ruiz, Hipólito: Relación histórica del viaje a los reinos del Perú y Chile, España).

31. Y esto equivale, señores, a tener en pie, arreglados, prontos a obrar los elementos de la guerra civil. Sobre este punto apelo a la historia, y no sólo a la contemporánea y doméstica, sino a la de todas la naciones y edades, pues en todas se ha visto que fuerzas obedientes a amos diversos chocan unas con otras frecuentemente, $y$ de que donde hay tropas no dependientes del gobierno supremo sirven para auxiliar o servir a aquellos de quienes inmediatamente dependen, en proyectos o empresas, de rebelión o si no de tanto, de desobediencia y desorden. (1843-1844, Alcalá Galiano, Antonio: Lecciones de Derecho Político, España).

32. el señor don Manuel Gonzáles de la Vega, capitán / de fragata, graduado en la armada nacional, / 5 y comandante militar de marina, en comición / en esta provincia, dixo que haviéndosele participado / de que en la noche del día nuebe / del corriente llegó a este puerto en una canoa / el contramaestre Gerónimo Sierra, /10 berificando su desembarque por la playa / del barrio de 
San Román extramuros, sin / que se huviese presentado a esta comandancia / como debió hacerlo con arreglo a ordenanza (1820, "Persecución a Jerónimo Sierra por llegar al puerto de Campeche sin licencia", México, CORDIAM ${ }^{14}$.

\section{Verbo ser}

33. Yo les preguntaba qué iban a hacer, que era menester meditar cualquiera cosa, y de que se fueran con tiento en gastar, porque no sabíamos si la Providencia dispondría que fuera el último socorro. (c 1818, Fernández de Lizardi, José Joaquín: La Quijotita y su prima, México).

34. Sobre diez y seis onzas de la pasta colorada indicada anteriormente se toman ocho de pasta blanca de mazapán, y se cortan en tres pedazos desiguales cada una mezclándolos despues: se deja conocer que la idea es de que las coloradas representen la carne, y las blancas la grasa de la salchicha: (1822, Anónimo: El repostero famoso, amigo de los golosos, España).

Confusión de preposición (en todos los casos es la preposición en la que se sustituye por $d e)$ :

35. Abrazó aquél el partido, y se abrazaron: pero ya estaba de acuerdo con Montaño de que luego que lo abrazase, y le agarrase las manos, lo matase. (1812, Mier, Fray Servando Teresa de: Segunda carta de un americano al Español, México).

36. mas yo me hallo muy distante de conformarme con su modo de pensar en la materia. No, no enviaré a mi hija a la amiga tan fuera de tiempo. Estoy confiado de que eres buena madre y la quieres mucho, y por lo mismo no te será gravoso el cuidarla en tu casa, ni el sujetarte por ella o privarte de algunas diversiones. (c 1818, Fernández de Lizardi, José Joaquín: La Quijotita y su prima, México) ${ }^{15}$. 37. Cuando don Dionisio se impuso a fondo de que su hija había sido la autora de semejante daño, poco le faltó para afianzarla y darla una turda como la merecía; pero se contuvo por el respeto de su cuñado y los demás señores. (c 1818, Fernández de Lizardi, José Joaquín: La Quijotita y su prima, México). 38. Yá dije, como quedó / en consulta esta canalla; / pero todos convinieron / de que muriese quemada. (c 1850-1900, Fuentes, Pedro de: Doña Francisca la cautiva. Romance en que se refiere cómo es..., España).

39. Llegó, y al punto repara, / de que el tahur le jugó / una mano mal jugada: (c 1850-1900, Anónimo: Juan de Arévalo [Romances de ciego], España).

\footnotetext{
${ }^{14}$ Se trata de un ejemplo dudoso, pero podríamos pensar que estamos ante un caso de dequeísmo con sujeto: algo se participa a alguien.

${ }^{15}$ El verbo confiar rige habitualmente en pero en el corpus manejado se encuentran ocho casos en los que aparece con la preposición de. Quiero, asimismo, llamar la atención sobre el hecho de que esta preposición también se encuentra en algunos casos en los que el complemento no es una oración subordinada sino un infinitivo o un nombre: "y es como siempre he confiado de vuestra persona, buena industria,” (1830, Fernández Navarrete, Martín: Don Álvaro de Bazán, primer marqués de Santa Cruz, España); "se me ha hecho esta afrenta y agravio, y confiado de recibir la merced en todo muy cumplida," (1890, Medina, José Toribio: Historia del Tribunal del Santo Oficio de la Inquisición, Chile).
} 
Con lo avanzado hasta ahora, podemos hacernos una idea más o menos clara del panorama existente en el siglo XIX. Por un lado, se ha comprobado que no parece existir un incremento progresivo a lo largo del siglo sino que son el tipo de texto y el registro de los hablantes los que determinan una mayor o menor frecuencia en la aparición de los casos. También se ha podido observar - a continuación insistiré en este punto-, cómo es en los textos americanos donde esta estructura alcanza una mayor notoriedad. Por otro lado, en cuanto al tipo de verbos a los que acompaña, es necesario destacar que la presencia de verbos de comunicación, proceso cognitivo o emoción parece favorecer la aparición de dequeísmo. Asimismo, la función desempeñada por el sintagma encabezado por de que es básicamente la de complemento directo aunque puedan darse unos pocos casos de sujeto.

A la vista de estos datos, se hace necesario profundizar más en las causas que pueden provocar la aparición del dequeísmo. Y aquí entran en juego tanto factores lingüísticos como extralingüísticos.

\section{FACTORES QUE FAVORECEN LA APARICIÓN DEL DEQUEÍSMO}

\subsection{Factores extralingüísticos}

De carácter extralinguiístico serían factores como la procedencia de los autores de los ejemplos, su nivel cultural o el tipo de texto en el que aparecen dichos ejemplos. Estos factores parecen ser determinantes para la existencia de vacilaciones en el régimen verbal.

En primer lugar, quiero llamar la atención sobre la importante presencia de autores americanos (o españoles emigrados a América) frente a los hablantes peninsulares que usan estructuras dequeístas. En el siglo anterior solo un $37,38 \%$ de los casos de dequeísmo pertenecían a autores peninsulares frente a un 57,95\% de americanos y un 4,67 \% de filipinos (Serradilla, 2014). En el siglo XIX las diferencias son un poco menos abultadas: contamos con 116 ejemplos americanos, que suponen un 56,86 \% de los 204 ejemplos documentados ${ }^{16}$; con 86 españoles $(42,15 \%)$ y con dos procedentes de Filipinas $(0,98 \%)$. Podría decirse que en esta época hay un importante avance del dequeísmo en la Península, aunque, como ahora matizaré, no en todos los géneros textuales.

Se hace, así, imprescindible, prestar atención a los distintos tipos de textos en los que más frecuentemente aparece esta construcción y, en primer lugar,

${ }^{16}$ Por países, la distribución de ejemplos es la siguiente: Argentina 65; Ecuador 2; Venezuela 5; Cuba 3; Perú 5; México 8; Costa Rica 4; Chile 18; Uruguay 1; Colombia 1; y otros 4 de los que nos se precisa el país. 
hay que destacar la presencia de dequeísmo en un par de obras de género épico que intentan reflejar el habla gauchesca y que, como ya he señalado, resultan muestras de habla artificiales (66 casos). Le siguen en orden de frecuencia los casos que aparecen en los romances populares (30 casos) y los incluidos en documentos de prosa histórica (27). En novela o relato extenso encontramos un total de 23 ejemplos, pero es digno de señalar que muchos de los casos se recogen en el diálogo de personajes con registro vulgar. Con un amplio número de apariciones (16) destacaría, asimismo, el género epistolar.

También hay casos de dequeísmo en otros géneros discursivos, pero en estos su presencia es casi anecdótica: romance histórico culto: 1; documentos sobre comercio e industria: 4; tratados y ensayo: 7; ensayo político y militar: 4; biografía: 5; documentos notariales: 5; memorias y diarios: 4; relato breve: 2; salmos (traducción): 1; prensa: 2; recetarios de cocina: 1; comedia: 1, drama: 1 y discurso político y religioso: 4 .

Observamos, pues, que la presencia de dequeísmo es especialmente abundante en textos que reflejan la lengua popular o, incluso, la lengua oral (cartas, romances, diálogos en novelas...) y en textos de relatos históricos, sobre todo americanos. Su presencia, sin embargo, en novela culta, en ensayo, en teatro y en discursos con un alto grado de preocupación por el estilo es minoritaria. Véanse, en este sentido, algunos ejemplos en los que claramente se relaciona el uso del dequeísmo con un bajo nivel cultural, pues, aunque nos encontramos con datos extraídos de obras literarias, estos solo se ponen en boca de personajes poco cultivados:

40. ¿Cómo pude afigurarme / de que ese sanabicha / con su nariz de salchicha, / allí se fuera a olfatiarme / tan sólo para boliarme? (1853, Ascasubi, Hilario: Paulino Lucero, Argentina).

41. - Pus bueno - continúa Tanasio-; ahora resulta de que como los ensalzaos no quieren entrar, nusotros los españoles paez que estamos abocaos a juzgarlos pa que entren, porque resulta que el francés es poderoso, y el caso es echarle allá los ensalzaos pa que dé cuenta de toos. (1871, Pereda, José María de: Tipos y paisajes, España).

42. que no le iba a pasar nada, / si pronto, con claridá / y de buena voluntá, / confesaba de que aquel / envoltijo de papel / explicaba la verdá. (1872, Ascasubi, Hilario: Aniceto el Gallo, Argentina).

43. - ¡Hola, señorita! ¡Válgame Dios! Que sea noragüena. No sabía de que se había usted casao. Que sea por muchos años: ¡y qué reguapa que se ha puesto usted! ¡Vaya unas cosas que traigo! (1890, Picón, Jacinto Octavio: La honrada, España).

Así, la distribución de casos coincide en gran medida con los datos documentados en el siglo XVIII (Serradilla, 2014). Parece evidente que en los textos que reflejan un discurso elaborado la presencia de dequeísmo es poco probable pues los autores cultos son conscientes de que se trata de una contravención a la norma. 


\subsection{Factores lingüísticos}

Son muchos los factores lingüísticos que pueden favorecer la aparición del dequeísmo y, por tanto, muchas también las perspectivas desde las que se ha enfocado este fenómeno ${ }^{17}$. Antes de centrarme en los diversos argumentos esgrimidos, me detendré en una serie de casos particulares en los que son ciertos elementos del cotexto los que parecen provocar la aparición de la estructura no canónica:

Obsérvese, así, cómo el dequeísmo documentado en un ejemplo como el siguiente viene motivado por un caso de silepsis preposicional ya que se recoge el régimen del verbo anterior:

44. Si usted no lo toma muy por lo serio, no puedo menos de alegrarme y de aplaudir de que Aglaya sea nuestra Ródopis. (1882, Valera, Juan: Carta de 19 de febrero de 1882 [Epistolario de Valera y Menéndez Pelayo], España).

También en el siguiente ejemplo el dequeísmo puede venir condicionado por la presencia de un verbo pronominal o, simplemente, por necesidades métricas:

45. Luego si tú con la mía / uniste tu voluntad / con dulces lazos unida, / sábete de que ya estamos / (según las leyes divinas) / para con Dios desposados, (1887, Mendoza, Juan: Doña Teresa de Rivera. En que se declara cómo D. Manuel de..., España).

Por otro lado, hay casos puntuales en los que la aparición del dequeísmo puede deberse a la confusión de estructuras; véanse, así, ejemplos como el siguiente en el que, realmente, lo que se ha dado es un error en el uso del verbo, ya que su significado es el de 'recordar'. Ha habido una confusión entre acordarse de que y acordar que, que nos lleva a una construcción no canónica:

46. pero no tememos asegurar que estas ventajas mercantiles y estos recursos pecuniarios habrian sido mucho mayores, á haberse tomado con tiempo las medidas que indicaba mucho ha el estado de la América, de que á principios del verano último se habló muy circunstanciadamente en algunos papeles. Acordamos de que gentes asustadizas y de miras estrechas levantaron entonces los gritos al cielo, y censuraron amargamente que se reconociese, aunque con ciertas restricciones, la independencia americana, (1822, Anónimo: Concluye la revista de enero [El Imparcial, 2 de febrero] España).

También en el siguiente ejemplo parece darse un cruce de construcciones entre darse por entendido algo y darse por enterado de algo:

${ }^{17}$ Entre los estudios en torno a este tema podemos destacar los siguientes: Almeida (2009), Bentivoglio (2002), Guirado (2006), Delicado Cantero (2013a, 2013b y 2014), Martorell de Laconi (2003), Orellano (2008 y 2010), Sánchez Arroba (2001) o trabajos ya clásicos como los de Arjona (1978a y b), García (1986) o Rabanales (1974). 
47. Ahora bien, como este Borbón ha sido liberal, la Toscana, o sea la Italia, se ha creído en la precisión de hacerle funerales, mientras que el sitiado de Gaeta, fundándose en la mismísima razón, no se ha dado por entendido de que tal hombre fuera hermano de su padre. (1861, Alarcón, Pedro Antonio de: De Madrid a Nápoles pasando por París, el Mont-Blanc..., España).

Aparte de estos casos puntuales y ya desde una perspectiva más amplia, mencionaré las diversas hipótesis propuestas sobre la aparición y extensión del dequeísmo. En este sentido, Almeida (2009: 17-19) hace un resumen de las diferentes hipótesis que se han manejado en torno a los factores que condicionan la aparición del dequeísmo: semántico-pragmáticos, sociales-psicosociales y psicolingüísticos.

Según este autor (Almeida, 2009: 17-18), quienes defienden las hipótesis semántico-pragmáticas proponen lo siguiente:

[...] la preposición de siempre conserva el significado de 'distancia' o 'separación', de ahí que, independientemente de que se trate de un caso de dequeísmo o de la estructura estándar de que, el uso de de ante que tiene por misión: a) debilitar o atenuar el contenido de la cláusula principal de la oración [...], b) permitir que los hablantes mantengan una relativa distancia con respecto al contenido proposicional [...], c) reducir la subordinación de la cláusula que encabeza que [...], d) expresar que la fuente de la información que se transmite no es el propio hablante, sino otra persona [...], o e) focalizar o llamar la atención sobre el argumento que introduce la preposición [...]. Como puede observarse, en la mayoría de estas propuestas, el uso o no de la preposición se contempla como un recurso retórico que permite a los hablantes presentar la información con un mayor o menor grado de certeza.

Por otro lado, quienes proponen hipótesis sociales-psicosociales argumentan que el dequeísmo surge por algún tipo de ultracorrección, lo que, desde mi punto de vista, ha quedado demostrado históricamente (Martorell de Laconi, 2003).

Por último, también se deben citar las hipótesis psicolingüísticas, seguidas por el propio Almeida, que inciden en el hecho de que los hablantes tienden a repetir estructuras lingüísticas ya emitidas en el discurso; por lo que, así, la aparición de la preposición de en una secuencia podría favorecer la aparición de construcciones dequeístas.

En las páginas siguientes prestaré atención a las diversas propuestas y observaré si los datos del siglo XIX que estoy manejando confirman dichas hipótesis.

Un punto en el que insistía en Serradilla (2014) es en el hecho de que el dequeísmo, en principio, surge por motivos de confusión de régimen: bien por confusión de la preposición que se ha de utilizar (convenir en / convenir de), bien por confusión del tipo de complemento que acompaña al verbo (decir que / decir de que). Como argumentaba en dicho trabajo, parece evidente que si el hablante usa de que en unos contextos, cada vez en más como apuntaba en la 
introducción, pueden no resultarle obvias las restricciones a su uso. Y es que, como señala Barra Jover (2009a y b), estos casos de dequeísmo podrían interpretarse como variantes invisibles en el sentido de que, con frecuencia, el mismo hablante recurre a estructuras canónicas y dequeístas, incluso en un mismo párrafo, y ni él ni su interlocutor son conscientes de esta variación. Señalaba este autor:

Una variante invisible existe cuando un mismo locutor puede usar para la función A la variante $a_{1}$ y la variante $a_{2}$ sin tener consciencia de ello ( $\sin$ dominar la alternancia) y sin que ello dependa de la situación. Quisiera insistir en que lo que interesa es que se trate del mismo locutor y que solo tiene interés observar la variante desde un punto de vista idiolectal y teniendo también en cuenta que el receptor tampoco es sensible a tales variantes (Barra Jover, 2009b: 21).

Véase el siguiente ejemplo, que corrobora dicha hipótesis:

48. En vista de todo se resolvió unánimemente pedir al superior gobierno que por pronta providencia se cerrasen los puertos de este virreinato para todo efecto de Europa y Asia procedentes de Chile, Buenos Aires y Panamá, suponiendo que hay existencias para cuatro años sin que se alteren considerablemente los precios de la plaza, $y$ de que las expediciones que vengan directamente de España, bastan y aún sobran para mantener la actual baratura como sucede con los géneros puramente españoles (1816, Quirós, José María: Memoria de instituto en que se demuestra que los muchos puertos nuevamente habilitados en América..., México).

El autor de este texto usa indistintamente una estructura u otra, pues, desde su idiolecto, ambas funcionan como variantes invisibles. No obstante, parece que entre los hablantes cultos estas variantes empiezan a ser visibles y la no canónica comienza a estar estigmatizada; de ahí que resulte difícil encontrar dequeísmos en textos escritos por hablantes cultos. Recojo de nuevo unas palabras de Barra Jover (2009b: 21):

Existen también variantes visibles, marcadas sociológicamente o regionalmente (que viene a ser lo mismo). Ante ellas, el receptor puede reaccionar percibiéndolas como estigmatizadas o como elevadas. Por ejemplo, (2) es un caso de variante visible marcada en cualquier contexto, ya sea escrito u oral [...]: (2) Pienso de que no deberías hacerlo (estigmatización completa).

En el siglo XVIII aún no era tan evidente que estas construcciones se consideraran variantes visibles, tal y como lo son hoy para un número muy importante de hablantes, pero en el XIX una buena muestra de que para muchos el dequeísmo ya era una forma estigmatizada es el hecho de que en los textos en que se intenta imitar el lenguaje vulgar, como hemos visto en las obras de Ascasubi, se recurre al uso del dequeísmo. Recuérdese que, en todo caso, el cor- 
pus de este trabajo está constituido por textos escritos, ya que en la oralidad, en ocasiones, incluso en hablantes cultos, que son conscientes de que nos encontramos ante una variante estigmatizada, es posible localizar algún caso de dequeísmo surgido por otras motivaciones.

A continuación, me detendré en el análisis de algunas de las posibles explicaciones que, para el dequeísmo, se han dado en la bibliografía más reciente y se intentará observar si son aplicables a la realidad del siglo XIX.

Se ha señalado, desde una perspectiva semántico-pragmática, que el dequeísmo estaría relacionado con el hecho de que la preposición de funciona como un marcador de evidencialidad y su presencia en determinadas construcciones trae consigo un distanciamiento en el sentido de que el hablante se involucra menos en lo dicho ${ }^{18}$. Sánchez Arroba (2001), en esta línea ${ }^{19}$, afirma que la preposición $d e$ en las estructuras dequeístas supone que el hablante no tiene evidencia de que lo dicho sea cierto, o adquiere un compromiso mínimo con lo dicho. Para esta autora (2001: 54):

Según los datos, se confirma que los hispanohablantes de la norma limeña pueden expresar con el dequeísmo: 'evento no experimentado', 'inseguridad', 'voluntad de no compromiso o no involucramiento', 'valoración negativa del evento', 'contrariedad u oposición a las expectativas' y finalmente, 'desacuerdo'.

El distanciamiento (marcado por la persona verbal) parece claro, como se observaba también en los textos del siglo XVIII, pero se hace difícil confirmar que todos estos valores semántico-pragmáticos apuntados por Sánchez Arroba sean los predominantes en los documentos del corpus manejado. Esto no quiere decir que valores como los de negación, valoración negativa, contrariedad o desacuerdo no sean relativamente frecuentes, como ya se observaba en el siglo $\mathrm{XVIII}^{20}$, pero no son mayoritarios en el corpus manejado. No obstante, puede observarse la siguiente muestra:

18 Véanse, en esta línea, por ejemplo, los trabajos de Orellano (2008 y 2010) donde también se defiende que la presencia de la preposición supone una atenuación de la transitividad. Para profundizar en los valores semánticos de la preposición de véase Granvik (2012).

${ }^{19}$ Corrobora en este sentido las hipótesis de Érica García (1986).

20 Véanse estos ejemplos del siglo XVIII recogidos en Serradilla (2014): "Y con esto no soy más molesto. Hasta la vista, contando de que yo no voy más a España, con que no sé como nos veremos." (Puerto España y mayo 8 de 91. Andrés José Marín, Cartas desde América 2, BA) (negación); "le suplió don Pablo Rossell por mano del tutor 130 pesos en ropas y algunos reales; por cuya causa parece incompatible el creer de que de esa remitan malas noticias," (1796, abril, 26, Puerto Cabello (Venezuela) Carta de Bernardo Azcárate a don Tomás Cólogan (vecino del Puerto de La Orotava, Tenerife, BA) (contrariedad); "Acaso la sórdida avaricia de los que ocupan [103] los mayores puestos en Turquía viene de este principio: digo de que a cada paso son elevados a ellos los hijos de los más viles Oficiales; y este vicio de los Ministros, que siempre hace grave daño a los Estados, los ha hecho gravísimos a aquel Imperio;" (1742, Cartas eruditas y curiosas, Feijoo, CD) (valoración negativa); "En cuanto dice tu madre de que estás viuda, pues, 
49. Tambien las hay de Azogue; pero no se trabajan estas por falta de fomento, ni se puede asegurar de que tenga cuenta su laboreo hasta profundar mas su terreno y reconocerle personas practicas en esta materia. (c 1793 - p 1801, Ruiz, Hipólito: Relación histórica del viaje a los reinos del Perú y Chile, España). (negación).

50. Para que seas escritor de libros... necesario es tambien que veas en tí alguna señal de que esa es la voluntad de Dios; y yo teniendo á la vista casi todas las obras de V., en ninguna de ellas, incluso el Kempis, veo la tal señal, antes sí muchísimas en contra. Me temo pues mucho de que $\mathrm{V}$. padeciese ilusion cuando la vió. (1811-1813, Alvarado, Fray Francisco: Cartas críticas del Filósofo Rancio, II, España). (contrariedad).

51. De esto ha resultado que el Alcalde Salinas me ha perdido el respeto y me ha dicho públicamente que todos han de vender aguardiente y que así mismo les ha de dar licencia para que lo saquen generalmente, como también lo ha de vender él públicamente en los corredores de su casa, para ver si allí le iba yo á estorbar que lo vendiesen, y otras muchas desvergüenzas producidas contra mi honor, queriendo salvarse con decirme que él era de la patria y que había de ver por ella, dándome á entender de que yo hacía injusticia. (1812, Anónimo: Expediente de la insurrección de Guanacaste y Nicoya. Costa Rica). (valoración negativa).

52. Húboseme de argüir de que habia publicado como alocucion de la Junta lo que evidentemente yo no había publicado como tal. La prueba es palmaria. (1841, Gallardo, Bartolomé José: Alocución a los electores de diputados por la provincia de Madrid, España). (desacuerdo).

Por su parte, Bentivoglio (2002), desde posiciones similares, insiste también en que la preposición de funciona como un marcador de evidencialidad y considera que, en este sentido es fundamental tener en cuenta el concepto de "persona gramatical": "cuando el hablante es el que afirma, dice, se acuerda, se entera, etc. hay menos probabilidades de que la preposición esté presente; lo contrario ocurre cuando el hablante reporta algo que hace, dice, etc. una tercera persona". En este caso, y como ocurría en siglos anteriores, esta realidad parece confirmarse con los datos extraídos del corpus analizado: he localizado 9 casos en segunda persona, 34 en primera persona, 53 con formas no personales y 103 en tercera persona ${ }^{21}$, con lo que parece confirmarse la hipótesis de que es la tercera persona la que más favorece la aparición del dequeísmo. Estos datos coinciden con los manejados para Lima por Sánchez Arroba (2001: 50): "La frecuencia tan alta de esta construcción después de formas verbales no personales o en tercera persona se relaciona con el valor semántico de 'no experimentado', correspondiente a la modalidad Irrealis y con un grado bajo de agentividad".

como tú dices que has escrito tantas cartas y a ninguna te he contestado, te digo que si las hubieras escrito las hubiera yo recibido," (La Habana y enero 3 de 1786. Francisco Gil Cartas desde América 2, BA) (desacuerdo).

${ }^{21}$ Hay también cinco ejemplos de otras construcciones no verbales. 
Conviene recordar, en este sentido, las palabras de Guirado (2006: 135), que también considera el uso de la preposición como un marcador de evidencialidad:

En yo me doy cuenta, el hablante dispone de la persona gramatical para expresar la fuente de la evidencia: yo tengo evidencia = yo me doy cuenta; en cambio en ellos se dan cuenta, el hablante ya no dispone de la persona gramatical para comunicar que él tiene evidencia de lo que los otros se dan cuenta: yo tengo evidencia $\neq$ ellos se dan cuenta. [...]. Así la deixis proposicional explicaría por qué la tendencia al uso de la preposición aumenta cuando la fuente de la evidencia no es el hablante y por qué tiende a omitirse cuando hablante y sujeto gramatical coinciden (yo me doy cuenta $\emptyset$ QUE vs. ellos se dan cuenta DE QUE).

Por otro lado, y siguiendo la misma línea argumentativa, autoras como Guirado (2006: 145) o Sánchez Arroba (2001: 48) consideran también la variable "tiempo verbal" como determinante para la presencia del dequeísmo. Esta última afirma, respecto a los documentos de Lima que maneja.

El $61 \%$ de los dequeísmos analizados aparece después de infinitivos, gerundios y tiempos verbales en presente (no pasados). El hecho de que el presente se ubique entre los tiempos imperfectos que ven la acción en su transcurso y no tienen en cuenta sus límites temporales, explica la preferencia por el uso de "de" con verbos en este tiempo.

En el corpus del siglo XIX estas proporciones aumentan ya que el $74 \%$ de las apariciones de dequeísmo son con tiempos no pasados (53 casos con formas no personales, 6 con futuro, 6 con imperativo, 1 con condicional y 85 en presente de indicativo) y solo un $26 \%$ (53 ejemplos) aparecen con verbos en pasado. En este sentido, se da cierta progresión respecto al siglo anterior en el que la presencia de tiempos pasados alcanzaba un 36,44 \%.

Hasta cierto punto, pues, se podría considerar que el tiempo verbal es significativo para la aparición del dequeísmo; no obstante, datos como este o como el de la relevancia de la persona gramatical deben manejarse con cautela ya que el tipo de texto o, en general, el tipo de discurso son determinantes a la hora de la utilización de las formas verbales y suele ser más habitual, salvo en documentos personales, la presencia de la tercera persona que la de la primera; así como, a no ser que estemos ante un género narrativo, parece evidente que recurrimos más al presente que a los tiempos pasados. Para estar seguros, pues, de que estos criterios son absolutamente fiables para determinar la presencia de dequeísmos tendríamos que constituir un corpus en el que la cifra de construcciones en primera y tercera persona fuera la misma, y que lo mismo ocurriera en el caso de los tiempos verbales. Mientras esto no sea así, la valoración de los datos no puede alcanzar todo el rigor científico deseable.

Desde otra perspectiva y partiendo de explicaciones psicolingüísticas, Almeida (2009: 22) cita como uno de los factores que provoca el dequeísmo el fenóme- 
no denominado priming: "[...] el hablante tiende a repetir formas y estructuras lingüísticas que han sido mencionadas en el discurso anterior (prime)" y hace referencia a la presencia de la preposición de o incluso de la sílaba de como detonante para la aparición de una construcción dequeísta. En la documentación del siglo XIX que he analizado se observa que en 89 de los 204 ejemplos localizados $(43,62 \%)$ aparece la preposición $d e$, a los que habría que sumarles al menos siete casos más en los que aparece la sílaba de $(3,17 \%)$, con lo que parece que, efectivamente, el hablante suele verse determinado por la aparición de una estructura similar en el discurso, aunque no en tan gran medida como encontrábamos en el siglo anterior (Serradilla, 2014), cuando la presencia de preposición ascendía a un 55,14\%. Asimismo, he localizado algunos casos (7) en los que la presencia de una secuencia de que canónica parece determinante a la hora de que el hablante recurra al dequeísmo. A continuación, se muestran unos pocos ejemplos de dequeísmo que pueden haberse visto condicionados por la presencia de la preposición o la construcción de que:

53. Aún estaba yo en la Jefatura, cuando sucesivamente fueron llegando los Vecinos principales a felicitar al vencedor, y a ganar con sonrisas y lisonjas la fácil voluntad del cabecilla. Los Llamas, desmedrados y amarillos a consecuencia de los frecuentes sustos; Bermejo, que en su calidad de víctima sacrificada en aras de la bola, se atraía las miradas y aun quizá la envidia de los demás; Arenzana, esperando de que el nuevo orden de cosas traería el desembargo de la tienda; (1887, Rabasa, Emilio: La bola, México).

54. Era D. Gonzalo hombre pundonoroso, y de gran tesón en sus empresas y providencias, y por consiguiente vivió muy disgustado de no poder conseguir muchas de las cosas que había intentado en beneficio de estas Islas, viendo de que muchas de sus providencias dirijidas á este fin, habían dado resultados contrarios á los que con ellas se proponía; empezó á padecer tal melancolía, que sin encontrar alivio á sus padecimientos, por más remedios que le aplicaron para ello, fué agravándose el mal, (1895, Alcázar, José de: Historia de los dominios españoles en Oceanía, Filipinas).

55. y que a pesar de que los antecedentes me aseguran de que son vanos, todavía no los puedo echar de mí. (1822, Fernández de Moratín, Leandro: Cartas de 1822 [Epistolario], España).

56. Extraña que le toleren los Obispos de las Galias, y le echa en cara de que se jactase en su patria de que San Gerónimo no había podido responder á su elocuencia (1855-1875, Fuente, Vicente de la: Historia eclesiástica de España, España).

57. y como ven que las amenazas de las partes se atreven a dirigirse a sus superiores, se intimidan por ver decaído el poder y autoridad de quien les manda; de que asimismo resulta de que con dificultad podremos proceder contra los delincuentes de esta especie en adelante, (1890, Medina, José Toribio: Historia del Tribunal del Santo Oficio de la Inquisición en Chile, Chile) ${ }^{22}$.

22 Véase, sin embargo, un ejemplo de esta misma construcción, en el que no hay dequeísmo, pese a la presencia previa de de que: "manifestando en el público ser doctrina sana y corriente; 
También Almeida (2009) menciona otro factor como posible detonante del dequeísmo; se trata del "efecto mecánico", que hace referencia, por una parte, al hecho de que la relación entre las cláusulas sea directa o indirecta (es decir, con elementos intercalados, lo que, según este autor favorece el dequeísmo) y, por otra, a que las estructuras dequeístas guarden relación sintáctica o semántica con otras estructuras en las que el uso de la preposición sea canónico (recordar de que por la relación con acordarse de que). En este caso también he revisado la hipótesis de Almeida en mi documentación y, respecto al primer punto, se puede decir que en 60 de los ejemplos aparecen elementos intercalados entre el elemento rector y la completiva $(29,4 \%)$, y, aunque no es una cifra nada desdeñable, no parece suficiente como para confirmar su propuesta:

58. En su consecuencia dispuso la Municipalidad de que en este acto se nombren los comisionados para los fines indicados, a fin de que se haga con toda la decencia posible un obsequio y manifestación del regocijo y adhesión de la ciudad, (1825, Romero, Bernardo: acta [Documentos sobre la Batalla de Ayacucho], Perú).

59. y concluyó (el agente) por entregarse a los consejos de un abogado Oribista y Rosista, quien (por supuesto) le aconsejó que contestara al Gobierno de que Oribe tenía completo derecho como beligerante para establecer bloqueos, habilitar puertos, y robar a troche y moche. (1853, Ascasubi, Hilario: Paulino Lucero, Argentina).

60. Y sin otro particular por hoy te deseo buena y completa salud, por la que no se me pasa día sin rogar, así como de que tengas una feliz suerte si te conviene. Adiós, adiós, tu hermano (Pedro Jado a su hermano Ventura, Escalante, 1855 junio, 12. Para hablarte, XIX, 2, BA).

En lo que tiene que ver con la hipótesis analógica, esta parece demostrada a lo largo de nuestra historia linguiística. Véase una mínima muestra:

61. Tambien las hay de Azogue; pero no se trabajan estas por falta de fomento, ni se puede asegurar de que tenga cuenta su laboreo hasta profundar mas su terreno y reconocerle personas practicas en esta materia. (c 1793 - p 1801, Ruiz, Hipólito: Relación histórica del viaje a los reinos del Perú y Chile, España) ${ }^{23}$.

62. de campaña Rodulfo tomó su asiento, Esperando de que entrasen Todos los aventureros, Que asoman por (1822, Anónimo: Romances, en Rodulfo y Casandra. Pliego suelto, España) ${ }^{24}$.

\footnotetext{
de que asimismo ha resultado que los ministros de este Tribunal en el reino de Chile, a quienes les habíamos encargado algunas prisiones de los discípulos y cómplices de dicha doctrina, después de esta novedad, lo hayan suspendido, por hallarse desautorizados y sin poder para perseguir por malo lo que la universidad del pueblo generalmente aprueba;" (1890, Medina, José Toribio: Historia del Tribunal del Santo Oficio de la Inquisición en Chile, Chile).

${ }^{23}$ Asegurar de que - asegurarse de que, estar seguro de que.

${ }^{24}$ Esperar de que - tener esperanza de que.
} 
63. Posteriormente, la negociación que ha hecho el interesado con el documento reconocido, acredita de que está seguro de que se le mandará pagar, porque, en realidad, más difícil es el reconocimiento de una deuda extraña, que la orden de satisfacerla. (1833, Paredes, José Gregorio: "Al Ministro García del Río" [Epistolario], Ecuador) ${ }^{25}$.

64. Rodrigo ¿En ese pueblo? / Gabriel Sí tal. / Rodrigo No recuerdo de que allí... / Gabriel Al rey de España en él vi / junto al rey de Portugal. (1849, Zorrilla, José, Traidor, inconfeso y mártir, España $)^{26}$.

A la vista de lo presentado hasta el momento, es posible observar cómo son muchas las explicaciones vertidas por los distintos investigadores para justificar la presencia del dequeísmo en español y cómo estas explicaciones parten de presupuestos muy diferentes. Asimismo, y teniendo en cuenta los datos con los que contamos, se hace evidente que algunas de ellas son más fáciles de demostrar que otras.

\section{CONCLUSIONES}

Como ya había sido observado en el siglo XVIII (Serradilla, 2014 y 2015), las estructuras que hoy son consideradas canónicas son las predominantes en el español del siglo XIX. Asimismo, en esta época la presencia del dequeísmo es mucho más frecuente que en el siglo anterior, lo que puede comprobarse por el hecho de que en el corpus analizado los casos de dequeísmo prácticamente duplican los aparecidos en la centuria anterior (204 frente a 107).

Aunque su aparición en los textos escritos es aún minoritaria, es de suponer que en la lengua hablada, sobre todo en la lengua coloquial o en registros bajos, su presencia debería de ser mucho más abultada, ya que en los casos en los que un autor pretende reflejar el habla popular, o incluso el habla vulgar, se recurre al uso del dequeísmo.

En el corpus que he manejado, de hecho, es relativamente frecuente encontrar casos de dequeísmo en las obras de Ascasubi, quien pone en boca de personajes poco cultos estas estructuras; al igual que ocurre en la obra de otros autores cuando intentan reflejar el habla propia de las personas menos instruidas. Asimismo, muchos de los casos documentados pertenecen a la lírica romanceril, de carácter popular. Por otro lado, de este análisis se desprende que, aparte de los casos mencionados, es en textos epistolares o en documentos históricos en prosa donde la presencia del dequeísmo es más importante, mientras que en textos literarios o más cuidados formalmente, su aparición es casi anecdótica. Lo seña-

\footnotetext{
${ }^{25}$ Acreditar de que - dar la acreditación de que.

${ }^{26}$ Recordar de que - acordarse de que.
} 
lado hasta el momento nos permite afirmar, pues, que el nivel cultural de los hablantes, así como el tipo de texto, tiene un papel relevante en la aparición del dequeísmo, que suele encontrarse en situaciones en las que prima la función comunicativa y la preocupación estilística queda relegada a un segundo plano.

Por otro lado, no puede perderse de vista la procedencia de los hablantes a la hora de analizar el dequeísmo: el 56,86 \% de los 204 casos documentados procede de América y el $42,15 \%$ de España. Estas diferencias son menos abultadas que en siglos anteriores, pero es importante señalar que en el corpus analizado hay bastantes más textos españoles que americanos, por lo que, aunque se percibe un incremento del dequeísmo en el español peninsular del siglo XIX, es evidente que su presencia en América sigue siendo claramente mayoritaria.

También es de destacar que, aunque en la última década del siglo parece haber cierto repunte de los casos de dequeísmo respecto a décadas anteriores, la presencia de esta construcción en el corpus manejado se mantiene relativamente estable, y no hay datos que avancen con claridad la eclosión de este fenómeno en el siglo $\mathrm{XX}$.

Aparte de los datos cuantitativos y de los factores extralingüísticos que favorecen la aparición del dequeísmo, en este trabajo he prestado una especial atención al tipo de verbos con los que aparece y a las construcciones en las que es más habitual. Es de destacar que, al igual que ocurre en los demás periodos de nuestra historia lingüística, la presencia de dequeísmo se localiza mayoritariamente con verbos de comunicación, proceso cognitivo o emoción y, asimismo, la función desempeñada por el sintagma encabezado por de que es básicamente la de complemento directo aunque hay también algunos casos de sujeto. También se ha observado que en todos los casos la construcción dequeísta aparece pospuesta al elemento regente.

Por otro lado, en este estudio he prestado atención a ciertas hipótesis semántico-pragmáticas, sociales y psicolingüísticas que han sido postuladas por diversos autores como favorecedoras del dequeísmo. Dentro de las primeras, se considera que el hecho de que la preposición funcione como un marcador de evidencialidad que indica distanciamiento favorece la aparición de dequeísmo, sobre todo, en el caso de que se utilice la tercera persona o el tiempo no pasado, como así ocurre en muchos de los ejemplos del corpus manejado; aunque una hipótesis como esta no permite explicar todos los casos de dequeísmo documentados.

Han sido tenidas en cuenta también hipótesis sociales o psicosociales que defienden que la ultracorrección está en la base de muchos de los casos de dequeísmo, dado que las dudas de los hablantes pueden llevarlos al uso de estructuras no canónicas.

Desde hipótesis psicolingüísticas, por otra parte, se afirma que el hablante tiende a repetir estructuras ya presentes en el discurso o a establecer analogías 
con construcciones relacionadas sintáctica o semánticamente. El establecimiento de analogías está presente en nuestra lengua desde los orígenes y ha podido ser observado entre verbos con similitud semántica o entre verbos y nombres con significado o forma similar a lo largo de la historia del español. En lo que atañe a la repetición de estructuras, se ha podido observar también que la presencia de la preposición de o de la secuencia de que propicia en algunos casos la aparición de construcciones dequeístas.

De todas formas, no parece que ninguna de estas hipótesis pueda por sí sola dar cuenta de todos los casos de dequeísmo documentados. La casuística es muy variada y es necesario acudir a una conjunción de factores que son los que favorecen la aparición de estas estructuras no canónicas. Asimismo, es preciso recordar que todas estas motivaciones solo resultan eficaces en determinados tipos de discurso. En español contemporáneo es evidente que la presencia de dequeísmo es mucho más frecuente en textos orales, sobre todo de carácter coloquial, y en la lengua de individuos con un nivel cultural bajo. No contamos, obviamente, con datos orales puros del habla del XIX, pero sí contamos, como ya he avanzado, con documentos que recogen formas más coloquiales o que intentan reflejar la oralidad o, incluso, el habla de personas poco instruidas y es, precisamente, en estos textos — donde la presión normativa es mínima-, en los que la aparición de casos de dequeísmo es más significativa.

Los posibles factores desencadenantes de esta variación linguiística no parecen ejercer, por tanto, influencia en los hablantes cultos; de la misma manera que no se vislumbra su influencia en los textos en los que se percibe una preocupación estilística o en los que la presión normativa se hace más evidente. Me he referido en este trabajo al concepto de "variante invisible", acuñado por Barra Jover, y creo que se trata de un concepto que nos permite explicar los diferentes casos de dequeísmo, ya que determinados hablantes, con un mínimo conocimiento de la norma lingüística o en condiciones en las que la preocupación por la norma es prácticamente inexistente, recurren a estas construcciones no canónicas, junto a otras respetuosas con la norma. Es cierto que diversos factores como los mencionados arriba pueden favorecer el uso de una u otra construcción, ya que para estos hablantes las construcciones con o sin de funcionan de la misma forma y no son conscientes de estar utilizando una u otra —no hay casos de personas que sean dequeístas siempre-, pero también es evidente que para los hablantes cultos del siglo XIX, como empezaba a serlo en épocas anteriores, las construcciones dequeístas se han convertido ya en variantes visibles estigmatizadas y en su discurso formal no recurren a ellas.

Puede afirmarse, pues, que son muchos los factores que se entrecruzan para favorecer la aparición de dequeísmo, pero la realidad del siglo XIX nos orienta en una dirección clara, que ya se comenzaba a observar en el siglo anterior y que continuará en el español actual: la situación comunicativa y el nivel cultural 
del hablante son aspectos fundamentales que deben tenerse en cuenta a la hora de explicar estas construcciones, que suponen una variación lingüística, pero que no han llegado a convertirse en un cambio lingüístico por la presión ejercida por la norma académica.

\section{REFERENCIAS BIBLIOGRÁFICAS ${ }^{27}$}

Almeida, Manuel (2009): "Priming y efectos mecánicos en la variación lingüística: el (de)queísmo en una comunidad canaria”, Boletín de Filología, XLIV, n. ${ }^{\circ}$ 1, pp. 11-37.

Arjona, Marina (1978a): "Anomalías en el uso de la preposición «de» en el español de México", Anuario de Letras (México), XVI, pp. 67-90.

Arjona, Marina (1978b): "Usos anómalos de la preposición de en el habla popular mexicana", Anuario de Letras, XVII, México, pp. 167-184.

Barra Jover, Mario (2009a): "Des variantes invisibles à la fragmentation des langues romanes", Recherches Linguistiques de Vincennes, vol. 38, pp. 107-132.

Barra Jover, Mario (2009b): "Las «variantes invisibles». Dos ejemplos del paso del español medieval al clásico", en La transformación del castellano medieval: sistema, formas de transmisión y entorno social, número monográfico de Cahiers D’Études Hispaniques Médiévales, 32, pp. 17-32.

Barrio, Florencio del (2005): El régimen de los verbos en español medieval, tesis doctoral, Alicante, Biblioteca Virtual Miguel de Cervantes/Universidad de Alicante, vol. 1.

Bentivoglio, Paola (2002): "La variación sociosintáctica en español", en II Congreso Internacional de la lengua española, <http://congresosdelalengua.es/valladolid/ponencias/unidad_diversidad_ del_espanol/1_la_norma_hispanica/bentivoglio_p.htm>.

Canet Villar, Georgina (2012): Una aproximación al dequeísmo desde la perspectiva diacrónica, tesis de máster, Barcelona, Universidad Autónoma de Barcelona.

Cano Aguilar, Rafael (1977-1978): "Cambios en la construcción de los verbos en castellano medieval”, Archivum, XVII-XVIII, pp. 335-379.

Cano Aguilar, Rafael (1985): "Sobre el régimen de las oraciones completivas en español clásico", en Philologica Hispaniensia. In honorem Manuel Alvar, vol. II: Lingüística, Madrid, Gredos, pp. 81-93.

CORDIAM = Academia Mexicana de la Lengua, Corpus Diacrónico y Diatópico del Español de América, <www.cordiam.org>.

Delicado Cantero, Manuel (2013a): Prepositional clauses in Spanish. A Diachronic and Comparative Syntactic Study, Berlin, De Gruyter Mouton.

Delicado Cantero, Manuel (2013b): "Clausal Substantivization in Spanish: Syntax and Constraints”, Australian Journal of Linguistics, 33.2, pp. 106-120.

Delicado Cantero, Manuel (2014): "Dequeísmo and queísmo in Portuguese and Spanish", en Patricia Amaral y Ana Maria Carvalho (eds.), Portuguese-Spanish Interfaces: Diachrony, synchrony, and contact, Amsterdam, John Benjamins Publishing Company, pp. 95-120.

García, Erica (1986): "El fenómeno (de)queísmo desde una perspectiva dinámica del uso comunicativo de la lengua", Actas del II Congreso Internacional del Español de América, México, Universidad Nacional Autónoma de México, pp. 46-65.

27 Obviamente, los trabajos sobre dequeísmo son muchos más de los que a continuación se recogen, pero se ha optado por incluir solo los que se han citado en el cuerpo de esta investigación. 
Granvik, Antón (2012): Estudio histórico-comparativo de los usos y la semántica de la preposición de en español, tesis doctoral, Mémoires de la Société Néophilologique, LXXXIV, Helsinki, Société Néophilologique de Helsinki, <https://helda.helsinki.fi/bitstream/handle/ 10138/28820/dedeestu.pdf?sequence $=1>$.

Guirado, Krístel (2006): "Deixis proposicional en el habla de Caracas: un análisis cuantitativo del (de)queísmo", Boletín de Lingüística, XVIII, pp. 130-156.

Martorell de Laconi, Susana (2003): "Acerca de los fenómenos lingüísticos de retención o arcaicos caracterizadores del habla salteña”, Boletín de la Academia Argentina de Letras, LXVIII, $\mathrm{n}^{\circ}$ 267-268, pp. 96-120.

Moral, Gabriel del (2008): "Spanish Dequeísmo: A Case Study in Subjectification", Nueva Revista de Lenguas Extranjeras, 10, pp.183-214, <http://bdigital.uncu.edu.ar/2643>.

Orellano de Marra, Verónica (2008): " $D E$ como conector: «quejarse que» versus «quejarse de que» en diacronía", en Actas del XI Congreso de la Sociedad Argentina de Lingüística (SAL), Santa Fe: Facultad de Humanidades y Ciencias/Universidad del Litoral.

Orellano de Marra, Verónica (2010): "QUE versus DE QUE en español oral contemporáneo”, en Víctor M. Castel y Liliana Cubo de Severino (eds.), La renovación de la palabra en el bicentenario de la Argentina. Los colores de la mirada lingüística, Mendoza, Editorial Filosofía y letras de la Universidad Nacional de Cuyo, pp. 949-955.

Rabanales, Ambrosio (1974): "Queísmo y dequeísmo en el español de Chile", en Estudios filológicos y lingüísticos. Homenaje a Ángel Rosenblat en sus 70 años, Caracas, Instituto Pedagógico, pp. 413-444.

CORDE = Real Academia Española: Banco de datos (CORDE) [en línea], Corpus diacrónico del español, <http://www.rae.es> [14/10/2016].

Sánchez Arroba, M. ${ }^{a}$ Elena (2001): "Gramaticalización y dequeísmo en el español de Lima", Mercurio Peruano, 514, pp. 43-56.

Sánchez Lancis, Carlos (2006): "Omisión y adición de la preposición de en construcciones sintácticas del español medieval y clásico", Actas del VI Congreso Internacional de Historia de la Lengua Española, pp. 1087-1100.

Sánchez Lancis, Carlos (2012): "Periodización y cambio gramatical: el siglo XVIII, ¿frontera temporal del español?", en M. ${ }^{a}$ Teresa García Godoy (ed.), El español del siglo XVIII. Cambios diacrónicos en el primer español moderno, Berna, Peter Lang, pp. 21-51.

Sánchez Lancis, Carlos (2014): "Gramaticalización y (de)queísmo en español: una aproximación diacrónica", en Daniel Jacob y Katja Ploog (eds.), Autour de QUE / El entorno de QUE, Studia Romanica et Lingüística, Frankfurt, Peter Lang, pp. 183-204.

Serradilla Castaño, Ana (1995): "Sobre las primeras apariciones de construcciones preposicionales ante QUE completivo en español medieval. Factores determinantes", EPOS, XI, pp. 147-163.

Serradilla Castaño, Ana (1996): Diccionario sintáctico del español medieval. Verbos de "entendimiento y lengua", Madrid, Gredos.

Serradilla Castaño, Ana (1997): El régimen de los verbos de "entendimiento y lengua" en español medieval, Madrid, UAM.

Serradilla Castaño, Ana (2014): "El auge del dequeísmo en el siglo XVIII o la desestabilización del sistema. Historia de una variación lingüística", Zeitschrift fur romanische Philologie, 130, 4, pp. 928-955.

Serradilla Castaño, Ana (2015): "Decir de que o jurar de que: primeros casos de dequeísmo en el siglo XVIII", Actas del IX Congreso Internacional de Historia de la Lengua Española, Madrid/Franckfurt, Iberoamericana/Vervuert, vol. 1, pp. 1109-1121.

Fecha de recepción: 5 de octubre de 2015

Fecha de aceptación: 11 de noviembre de 2015 